\title{
PRODUCTION ENGINEERING EDUCATION IN INDIA
}

\author{
Sushant Khare ${ }^{1}$, Shrish Bajpai ${ }^{1}$, Dr.P.K. Bharati ${ }^{2}$ \\ ${ }^{1}$ Electronics \& Communication Engineering Department, Faculty of Engineering, Integral University, India \\ ${ }^{2}$ Mechanical Engineering Department, Faculty of Engineering, Integral University, India
}

Corresponding author:

Sushant Khare

B.Tech Pursuing, Electronics and Communication Engineering Department

Faculty Of Engineering

Integral University, Lucknow

Uttar Pradesh, India. Pin Code: 226024

phone: +91-7897-029250

e-mail: khareysushant@gmail.com

Received: 2 January 2015

Accepted: 1 February 2015

\begin{abstract}
Present paper deals with the field of Production Engineering specifically its standard of education in India. This discipline of engineering focuses on the capability of an engineer not just as a technician but also as a manager. As a result industry is also favoring the development of this field. This paper reviews the educational structure followed in India for engineering education. It aims to give a clear idea of standard of this discipline's courses being run in India at different levels of engineering, considering both centrally funded and private institutions. It also covers the necessary simulation tools used to train the students during these courses and inspects over available web-resources related to the subject. In the epilogue it discusses the future prospects for this field's development as a discipline and concludes with a brief comparison of India's status from other regions of world. In the end we have made some suggestions to decision-makers based on our findings to improve the existing model.
\end{abstract}

KEYWORDS

Production engineering, technical education system, production engineer, India.

\section{Introduction}

Production engineering is practice of manufacturing technology with management science as a professional. Its aim is to accomplish the manufacturing processes in an effective, efficient \& mosteconomic way. Production Engineering is a multidisciplinary field of engineering with management that rejects splitting engineering into separate disciplines. Production engineering is a professional engineering practice of manufacturing technology with management science. Its aim is to complete the production processes efficiently \& economically. A production engineer has a wide knowledge of different engineering practices (mechanical, instrumentation \& devices), scientific knowledge \& management skills to handle the real world problems. These abilities are fundamental for the performance of coordinating and integrating professionals of multidisciplinary different teams across the production process. In any industry, once the design is finalized, production engineering concepts regarding work-study, resource planning \& management, materials management and transportation play important roles in efficient production processes. Production engineering overlaps substantially with manufacturing engineering \& industrial engineering.

The aims of engineering education as suggested by various reports such as of Grinter, Finniston and others during the subsequent years of twentieth century suggest that engineering education should be designed in such a manner to enable a student to design with creativity, perform analysis, construction and production in such a way that it supplements the socioeconomic development [1]. To see whether these aims are getting fulfilled or not, continuous assessment and evaluation is necessary.

Before nineteenth century, production engineering was covered as a subject in mechanical engineering curriculum \& there was no separate department 
or specialized program for that. Production engineering got attention in Second World War when its principles were used in the manufacturing of fighter planes in USA. After 1950, due to rapid development of industry in many countries, there was a great need of professional production engineer, who can drive the production in a smoothest way. Initially, production engineering ran as a subject "production technology" for mechanical engineering or physics with material specialization students and after that it was included as an independent engineering discipline across the globe in different technical institutes.

India is the seventh largest country in world by area \& second largest county by population with biggest population of young people in the world. But, what matters the most is that it has one of the largest number of engineering students in the world. The quality of engineering education in the IITs is considered to be at par with world's top technical universities [2]. Since independence of India, industrialization process started through Public Sector Units (PSU), manufacturing sector got accelerated and there was a great demand of skilled production engineers across the industry. Indian government has launched a program "Make in India" as a call for world's leading manufacturers to set up their units in India. As manufacturing activities play a vital role in the development of the country, India envisaged the need for trained manpower in manufacturing sector to tackle the requirement generated by such initiatives. A proper educational system not only supports the financial structure but also ensures sustainable development [3]. In the subsequent sections we will shed light on the technical education system followed in India.

Present paper is divided into three parts; first we have discussed about the production engineering education in India at diploma, undergraduate, postgraduate, doctoral \& post doctoral level, then future scope of production engineering in different industry with the employment of production engineers and at last conclusion of production engineering education in India.

\section{Production engineering in India}

\section{Basic structure of engineering education in India}

India has a good number of engineering educational institutes with technical polytechnics, which provides undergraduate degree in 45 major engineer- ing disciplines \& around 60 major polytechnic courses. Admission in polytechnic course is done by state level test, conducted by the state government technical department in India. Admission in UG programs in technical institutions in India is done by JEE (Joint Entrance Examination), conduct by CBSE for Indian Institute of Technology (IIT), National Institute of Technology (NIT), Indian Institute of Information Technology (IIIT), with some other technical dream universities \& institutions. State level entrance exams for UG admission has been conducted by state government technical department for technical institutes govern by state government of that state. Private technical institutions generally used the merit of these two exams for UG admission in their campuses, but some also take their own entrance examination. Admission to PG course in technical institutions is done through GATE (Graduate Aptitude Test in Engineering) conducted by any one Indian Institute of Technology. Some institutes take their own test and interview, after short listing the candidates with valid GATE score. Doctoral admission is done by respective department of the institute, which conduct test (based on specialization or field chosen by candidate) followed by interview. Postdoctoral admission is done through interview only base on research proposal submitted by candidate.

Polytechnic course has around 25-30 theory courses and 6-10 practical courses. Undergraduate level course B.E./B. Tech. is of four year or three years (for diploma holders), eight semester or six semester having 25-35 theory courses with 15-25 laboratory course along with the final year major project. Postgraduate level course M.E. /M. Tech. is of two year having four semesters consisting of 10 theory \& 2 laboratory courses with the final semester completely dedicated to their disquisition in their specific chosen field. Apart from this, MS degree program is also offered by some technical institutions which. MS programs are more focused towards real time research. Doctoral degree offered by established technical institutions in full time or part time research mode in which candidate have to complete course work consist of $2-4$ subjects according to his research topic approved by his guide. Scholarship is provided by some funding agency to the doctoral students who register as full time research scholar. Post doctoral is offered by few top institutions which focus on practical problem of real world \& associated to the any industry specific. Dual degree programs ( $\mathrm{UG}^{1}$ with $\mathrm{PG}^{2}$ \& $\mathrm{PG}$ with Doctoral) also offered by some technical institutions in India [4-14].

\footnotetext{
${ }^{1} \mathrm{UG}$ - Undergraduate.

${ }^{2} 2 \mathrm{PG}$ - Postgraduate.
} 


\section{Specifics of production engineering}

Production engineering as a subject "Production Technology" got stated in Mechanical engineering department in many technical institutes as optional subject but due to its potency power in different industries, it was started as engineering discipline. After independence of India, first dedicated department of "Production Engineering" was established at Veermata Jijabai Technological Institute (Formally Victoria Jubilee Technical Institute), Mumbai in 1959 to conduct part time course leading to postgraduate diploma in production engineering for nearby industries. After that "Department of Production Engineering" opened at Birla Institute of Technology 1964 to fulfill the demand of skill trained engineers in nearby eastern India industrial hubs. "Production and Industrial Technology" department established at PEC Chandigarh in the year 1967 who offered UG engineering degree in "Production and Industrial Technology" for northern India. Production Engineering as independent engineering disciple established at PSG College of Technology in 1975. Many technical institutions in India offer "Production Engineering" as UG degree course under the mechanical engineering department or industrial engineering department. Today, many NITs have a separate department for the production engineering.

\section{At Diploma-level}

Diploma courses in production engineering offered by few polytechnics across India. In diploma, production engineering has common subjects with mechanical \& electrical engineering with basic science subjects. AICTE (All India Council for Technical Education) has approved and given a model for diploma level courses on production engineering.

\section{At Undergraduate level}

At UG level (B.E./B. Tech) there are about 8-10 core subjects which are directly associated with production engineering, rest of them are related to materials engineering, mechanical engineering, electrical engineering, management \& couple of interdisciplinary courses. Lab work is done in the field of Welding, Casting, Mechatronics, Instrumentation, Simulation, Composite materials \& Operations Management. UG curriculum includes a major project which is done in the final semester on the field robotics, machine design, instrumentation, welding, control engineering, casting etc. The UG course of production engineering at NIT Trichy has laid out a proper format which includes appropriate courses from electronics, electrical and mechanical engineering \& other departments [5].

\section{At Post Graduate, Doctoral and Post-doctoral level}

Post graduation course in production engineering is offered by few technical institutions in which student have to complete the theory \& practical course with the dissertation. Major theoretical topics studied under it include linear control theory, Facility Planning \& Design, Metal Forming Technology, Optimization Techniques, and Foundry Technology etc. Students have to defend his/her dissertation before an audience which includes an examiner from another institution in India. Doctoral research in production engineering is done in the field of design, manufacturing, work design \& ergonomics, total quality management, machining, welding, casting, value engineering, resource management etc. At doctoral level, students do theoretical or real issue analysis for their doctoral thesis. Some research projects funded by funding agency may form a part in their research work.

Post doctoral level research in Production Engineering is not offered by any institutions in India.

Figures 1 and 2 gives the overall statistics of Production Engineering (UG and PG) in Indian Institutes of Technology (all sixteen).

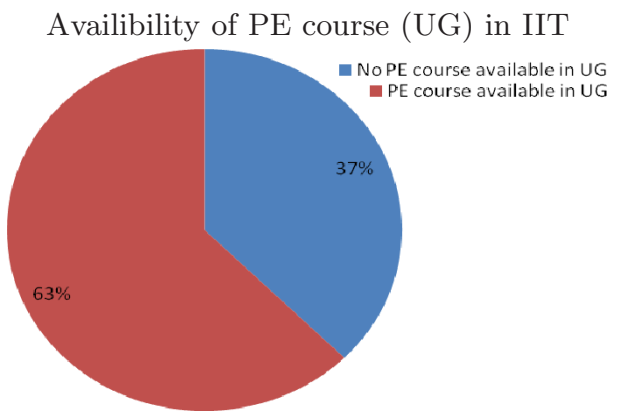

Fig. 1. Production Engineering (UG) at IITs.

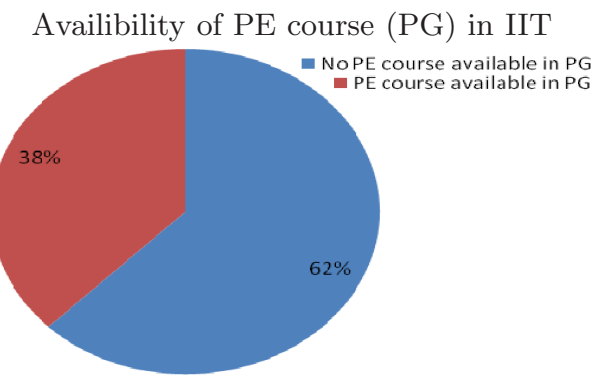

Fig. 2. Production Engineering (PG) at IITs.

\section{A note on literature}

Due to the nature of work, many subjects took by students during undergraduate course of production engineering are same as those took by mechanical undergraduate students. As a result, there are 
plenty of books available on the subjects taught during the course. For subjects such as applied electronics, applied electrical and other courses related to electrical or electronics technology many standard texts from internationally renowned authors such as R.L. Boylestad, Louis Nashelsky, and Adel S. Sedra are available and generally preferred. However, texts from Indian authors such as Ramakant A. Gayakwad, D. Roy Chaudhary and J.B. Gupta are also used as textbooks for such subjects [7]. While for subjects who have mechanical engineering roots like thermal engineering, strength of materials and other such subjects; various Indian authors have contributed. Some notable works are of S. Ramamurtham, V. Ganesan etc [8, 9]. Some authors who have contributed specifically to the field of production technology are K.C. Jain, Groover, and P.C. Sharma etc.

\section{Available simulation tools and web-resources}

MATLAB, NI-LabVIEW, Mathematica are the major simulation tool used for solving mathematical computation problems. Scilab, GNU Octave, Maxima, Freemat and R are some open source tools useful for solving mathematical computation problems. An appreciable effort from Indian government's Ministry of Human Resource and Development (MHRD) the online dissemination of knowledge for free in form of video lecture courses and assignments under the program known as NPTEL [10]. There are several courses which are useful for both production and mechanical engineering are already uploaded on this website such courses on Manufacturing Processes, Planning and Control $[11,12]$. But as we move forward there is a need of introducing courses targeted for Production engineering.

The Shodhganga at INFLIBNET is set-up using open source digital repository software called DSpace developed by MIT (Massachusetts Institute of Technology) in partnership between Hewlett-Packard. The DSpace uses internationally recognized protocols and interoperability standards. Shodhganga provides a platform for research scholars to deposit their $\mathrm{Ph}$.D. theses and make it available to the entire scholarly community in open access. The repository has the ability to capture, index, store, disseminate and preserve ETDs (Electronic Theses and Dissertations) submitted by the researchers [12].

\section{Future scope of production engineering}

There is no such industry in the world that does not require production engineering. The most common trend is that students pursuing graduation go for some job provided by software industries so as to earn their livelihood. Post graduate students are keener to their academics or are interested in further research in same institute or other higher doctoral based institutes.

No direct provisions as production engineering are made in the curriculum of Indian Engineering Services (IES); students enrolled in production engineering have to fulfil the norms through the mechanical engineering course. People are hired as mechanical engineers, rather than production engineers at various Public Sector Units. Jobs for a production engineer are available under the field of mechanical engineering at both central \& state level government. Doctoral students are hired by various organizations such as Defense Research Development Organization, Indian Space Research Organization, Atomic Energy Department of India, Private Research Firms and many more. Many research scholars get employment as the teaching staff in various technical institutions\& polytechnics. Due to less amount of simulation labs \& online labs, there is no or very slight collaboration among the different institutions across the India.

Success of Chandrayaan-I, Mangalyaan (Mars Orbiter Mission) \& various other projects under the ISRO has motivated the organization for other future launches which requires high level of expertise in the production of different parts which will demand for new skilled production engineers. A short time ago, the Indian government inculcate the FDI in defense sector due to which people not belonging to India will migrate and setup new industries in India. This will in turn necessitate the production engineers.

\section{Conclusions}

Production Engineering is the most necessary field of engineering for the proper development of industries in any developing or developed nation. As the time is passing more \& more students are getting motivated to get them enrolled to the courses offered across the India. Production Engineering itself is a big discipline of engineering and many fields run together inside it, so it is necessary to bifurcate it into different kinds of specialization so that students can enroll themselves according to their interests.

\section{Brief comparison from institutions of Europe, North America and South America}

We have used Quacquarelli Symonds (QS) ratings for the selection of colleges as they are accepted throughout the world [13]. We have taken top ten colleges from different regions specifically based on their 
rankings in Mechanical, Aeronautical and Manufacturing Engineering disciplines.

Europe has a number of colleges which are consisted one of the best in the academia. United Kingdom, Germany and Netherlands have highly reputed institutes of the discipline. Out of top five institutes of Europe, four were found to have courses running on production or manufacturing engineering at either undergraduate or graduate level. The employability of students pursuing a course there is also reasonably high. When compared to India's status Europe appears to have a clear edge in every perspective.

When compared to North American and South American institutes, Indian institutes were found to be better in rankings than South American institutes but far behind the North American institutes. While a course related to production engineering was available at every institute among top five of South American institutes; four out of five institutes from North America were having a course. Other than ratings, India has a clear edge on South American institutes in terms of employment opportunities. While Indian institutes lack some features like academia-industry relationships and composition of faculty and students from all over the world. Availability of these features gives North American institutes highest rankings and repute worldwide.

We suggest that the government should work upon its policies and revise their norms so that production engineering gets its separate identity, instead of its merger with the mechanical engineering. There is a disproportion in the quality of education between centrally funded institutions \& private institutions; this generates division in the students of same rank. This cannot be removed but can be improved by providing funds to the different institutions at different levels by the Indian Government. Increase in the quality of thinking \& the course curriculum will help the students to pursue their research interests. Consultancy in manufacturing, design and industrial engineering, improvements in institute-industry relations \& interactions and equipment of laboratories are some significant donation to the education, especially regarding Production Engineering.

\section{References}

[1] Heywood J., Engineering Education: Research and Development in Curriculum and Instruction, John Wiley and Sons, pp. 4-8, 2005.
[2] Sajal K. Palit, The Development of Engineering and Technical Education in India, Global Journal of Engineering Education, 2, 3, 317-326, 1998.

[3] Goel V.P., Technical and vocational education and training (TVET) system in India for sustainable development, Bonn, UNEVOC, 2011 http://www.unevoc.unesco.org/up/India_Country _Paper.pdf [Accessed January 20, 2015].

[4] Sushant Khare, Shubham Chowdhry, Shrish Bajpai, Control Engineering Education in India at 3rd International Conference on Power, Control and Embedded Systems (ICPCES - 2014), IEEE at M.N.N.I.T., Allahabad, India.

[5] Department of Production Engineering, NIT Tiruchirapalli, Tamil Nadu. India, www.nitt.edu/ home/academics/departments/prod//, accessed on January 20, 2015.

[6] Jange S., Pasha M.G.G., Vaddenkeri M., Nirale R., Technical education and e-resources in India: Prospects and developments, International Conference on Financial Theory and Engineering (ICFTE), IEEE, pp. 155-159, 2010.

[7] Ramakant A. Gayakwad, Op-amps and Linear Integrated Circuits, Prentice Hall, 2000.

[8] D. Roy Choudhury, Shail Jain, Linear integrated circuits, Wiley, 1991.

[9] Ganesan V., Internal Combustion Engines, Tata McGraw-Hill, 2003.

[10] Moudgalya K.M., Phatak D.B., Shevgaonkar R.K., Engineering education for everyone a distance education experiment at IIT Bombay, 38th Annual Frontiers in Education Conference, IEEE, pp. T3C21-T3C-26, 2008.

[11] Ananth M.S., National Programme on Technology Enhanced Learning (NPTEL): The Vision and the Mission, IEEE International Conference on Technology for Education (T4E), IEEE, pp. 8, 2011.

[12] Manoj Kumar K., Nirmal Chand, Savita Gandhi, Ontological Mapping for Semantic Search in Shodhganga: A National Repository of Electronic Theses and Dissertations (ETDs), INFLIBNET Centre, 2012, URI: http://hdl.handle.net/1944/1692, [accessed January 20, 2015], ISBN: 987-93-81232-02-6.

[13] Quacquarelli Symonds, http://www.qs.com/ [accessed on January 20, 2015].

[14] Shivani, Shashi Khurana, Technical Education System In India: Present Scenario, International Journal of Research in Economics \& Social Sciences, 2, 10, 39-49, 2012. 